PRINT ISSN 1119-8362

Electronic ISSN 1119-8362
Full-text Available Online at

https://www.ajol.info/index.php/jasem

http://ww.bioline.org.br/ja
J. Appl. Sci. Environ. Manage.

Vol. 25 (7) 1163-1166 July 2021

\title{
Studies on the Thermal Stability of Peroxidase from Leaf of Oil Palm (Elaeis guineensis)
}

\author{
${ }^{* 1}$ OZIOKO, JN; ${ }^{1 E Z E M A, ~ B O ; ~}{ }^{2}$ OMEJE, KO; ${ }^{2}$ EZE, SOO \\ Department of Science Laboratory Technology, University of Nigeria, Nsukka. ${ }^{2}$ Department of Biochemistry, University of Nigeria, Nsukka \\ *Corresponding Author Email: kingsley.omeje@unn.edu.ng
}

\begin{abstract}
Peroxidase was extracted from leaves of oil palm tree with 0.01M phosphate buffer $\mathrm{pH}$ 7.0. It was partially purified using $70 \%$ ammonium sulphate $\left(\left(\mathrm{NH}_{4}\right)_{2} \mathrm{SO}_{4}\right)$ precipitation. This resulted in peroxidase with activity of $(26 \mathrm{U} / \mathrm{ml})$ and specific activity of $35.8 \mathrm{U} / \mathrm{mg}$. Effect of heat on the activity of peroxidase was studied at temperature of 323 $363^{\circ} \mathrm{K}$. After gel filtration on sephadex G100, the peroxidase activity increased to $27 \mathrm{U} / \mathrm{ml}$, with specific activity of $55 \mathrm{U} / \mathrm{mg}$. The overall purification fold was 4 with $51.9 \%$ enzyme recovery. The peroxidase partially purified from leaves of oil palm tree showed $\mathrm{pH}$ and temperature optima of 5.0 and $50^{\circ} \mathrm{C}$ respectively. High pH and temperature stabilities of $\mathrm{pH} 5.0$ to $\mathrm{pH} 9.0$ and $50^{\circ} \mathrm{C}$ to $70^{\circ} \mathrm{C}$ were obtained respectively. Also, the activation energy (Ea) of the reaction was $21.616 \mathrm{kj} / \mathrm{mol}$. The free energy changes $(\Delta \mathrm{G})$ were $96008.64,96315.59,97901.63,94132.33$ and $97146.75 \mathrm{kj} / \mathrm{mol}$ at $323,333,343,353$ and $363^{\circ} \mathrm{K}$ respectively. It was observed that the D-values were decreasing with increasing temperature with a Z-value of 0.044 . The enthalpy results suggest that the reaction was exothermic, non-spontaneous and reversible.
\end{abstract}

\section{DOI: https://dx.doi.org/10.4314/jasem.v25i7.9}

Copyright: Copyright $\odot 2021$ Ozioko et al. This is an open access article distributed under the Creative Commons Attribution License (CCL), which permits unrestricted use, distribution, and reproduction in any medium, provided the original work is properly cited.

Dates: Received: 10 May 2021; Revised: 28 June 2021; Accepted: 01 July 2021

Keywords: peroxidase, oil palm leaves, temperature, $\mathrm{pH}$

Peroxidases (EC 1.11.1.7) are hemoproteins that catalyze the hydrogen peroxide $\left(\mathrm{H}_{2} \mathrm{O}_{2}\right)$-dependent oxidation of different substrates including phenolic compounds (Qayyum et al., 2010; Omeje and Eze, 2018). They are widely distributed in plants, animals and micro-organisms. It can be found in vacuoles, tonoplast, plasmalemma, cell wall, chloroplast and mitochondria with variable functions (Omeje et al., 2017; Idesa and Getachew, 2018). It is involved in plant hormone regulation, defense mechanisms, indole acetic acid degradation during maturation and senescence of fruits and vegetables, and lignin biosynthesis (Falade et al., 2019). Peroxidases have wide applications in different areas such as organic synthesis, medicine, pharmaceuticals and biotechnology (Veda et al., 2017). Earlier, Agunbiade et al (2021) reported the presence of peroxidase in higher plants such as Moringa oleifera leaves. African oil palm (Elaeis guineensis) leaves are among the tropical underutilized plants that have recently attracted worldwide attention. Nigeria is one of the nations of the world known for its production of palm trees. After harvesting the fruits, other by-products including the leaves are discarded indiscriminately, thereby causing nuisance to the environment. Up till now, there is still a dearth of information in literature on peroxidase from Elaeis guineensis (Rodriguez et al., 2002).

\section{MATERIALS AND METHODS}

Fresh oil palm (Elaeis guineensis) leaves used for this study were harvested from Nsukka, Enugu State, Nigeria. All chemicals were of analytical grade and reagents were freshly prepared, unless otherwise stated. O-dianisidine was purchased from SigmaAldrich.

Enzyme assay: Enzyme assay was carried out according to the procedure described by Eze et al. (2010)

Enzyme purification: Enzyme purification was done using the method described by Rodriguez et al. (2002)

Optimum $p H$ and temperature of peroxidase: The optimum $\mathrm{pH}$ for peroxidase activity was determined using $0.1 \mathrm{M}$ sodium acetate buffer $\mathrm{pH} 3.0-5.5,0.1 \mathrm{M}$ phosphate buffer $\mathrm{pH} 6.0-8.0,0.1 \mathrm{M}$ Tris- $\mathrm{HCl}$ buffer $\mathrm{pH} 8.0$ - 9.5 and glycine-NaOH buffer $\mathrm{pH}$ 9.5-10.5. The enzyme activity was assayed at different $\mathrm{pH}$ and read at absorbance of 460nm with Jenway 6303 spectrophotometer. The optimum temperature was determined by incubating the assay mixture for $20 \mathrm{~min}$ at $30-90^{\circ} \mathrm{C}$. After heating, it was allowed to cool for 5 mins and the enzyme was added and absorbance read at 460nm. (Eze, 2012). 
pH and temperature stability of peroxidase: A $2.4 \mathrm{ml}$ of the different $\mathrm{pH}$ buffers (Na-acetate buffer; 3-5.5, Phosphate buffer; 6-8.5, Tris-HCl buffer and Glycine$\mathrm{NaOH}$ buffer; 10.5) were incubated with $0.2 \mathrm{ml}$ of enzyme and assayed at different time for $2 \mathrm{hr}$ and absorbance was read at $460 \mathrm{~nm}$. Also, temperature stability was determined. In each case, $0.2 \mathrm{ml}$ of the enzyme was added in a test tube and heated in a water bath from 20, 40, 60, 80,100 and 120min respectively. The assay mixture was added after each time interval and the absorbance was read at 460nm with Jenway 6303 spectrophotometer (Eze, 2012).

\section{RESULTS AND DISCUSSION}

Peroxidase was extracted from the leaf of oil palm tree and partially purified using two purification processes of Ammonium sulphate precipitation and sephadex G100, gel filtration. Table 1 , shows the purification steps of peroxidase from oil palm leaves. The protein concentration of peroxidase decreased from $1.220 \mathrm{mg} / \mathrm{ml}$ for crude enzyme to $0.488 \mathrm{mg} / \mathrm{ml}$ after gel filtration while peroxidase activity increased from $17 \mathrm{U} / \mathrm{ml}$ to $27 \mathrm{U} / \mathrm{ml}$ as the purification step increased, and the specific activity also increased to
$55.4 \mathrm{U} / \mathrm{mg}$. The protein concentration of the crude extract was $1.220 \mathrm{mg} / \mathrm{ml}$, which decreased to $0.727 \mathrm{mg} / \mathrm{ml}$ after $\left(\mathrm{NH}_{4}\right)_{2} \mathrm{SO}_{4}$ precipitation. After gel filtration on Sephadex G-100, the protein concentration reduced to $0.488 \mathrm{mg} / \mathrm{ml}$. Peroxidase activity of the crude enzyme was $17 \mathrm{U} / \mathrm{ml}$, and after $\left(\mathrm{NH}_{4}\right)_{2} \mathrm{SO}_{4}$ precipitation and gel filtration, peroxidase activity increased to $26 \mathrm{U} / \mathrm{ml}$ and $27 \mathrm{U} / \mathrm{ml}$ respectively. This shows that peroxidase activity increased at every step of the purification process. This implies that, as the purification step increases, some proteins which serve as impurities were eliminated. Also the high activity of these steps suggested that the precipitation of the crude enzyme at $70 \%$ ammonium sulphate saturation did not damage the integral structure of the enzyme. The specific activity of the crude enzyme was $13.90 \mathrm{U} / \mathrm{mg}$, which increased to $35.80 \mathrm{U} / \mathrm{mg}$ and $55.46 \mathrm{U} / \mathrm{mg}$ after $\left(\mathrm{NH}_{4}\right)_{2} \mathrm{SO}_{4}$ precipitation and gel filtration respectively. This result corroborate the report by Omeje et al. (2019), who stated that for purification procedure to be successful, the specific activity of the desired enzyme must be greater than the former after each purification step. Peroxidase extracted from oil palm (Elaeis guineensis) leaves was purified four folds in this study.

Table 1: Purification table of oil palm leaves peroxidase

\begin{tabular}{lllllllll}
\hline Purification step & $\begin{array}{l}\text { Volume } \\
(\mathbf{m l})\end{array}$ & $\begin{array}{l}\text { Protein } \\
\text { Conc. } \\
(\mathbf{m g} / \mathbf{m l})\end{array}$ & $\begin{array}{l}\text { Total } \\
\text { protein } \\
(\mathbf{m g})\end{array}$ & $\begin{array}{l}\text { Peroxidase } \\
\text { Activity } \\
(\mathbf{U} / \mathbf{m l})\end{array}$ & $\begin{array}{l}\text { Total } \\
\text { activity } \\
(\mathbf{U})\end{array}$ & $\begin{array}{l}\text { Specific } \\
\text { activity } \\
(\mathbf{U} / \mathbf{m g})\end{array}$ & $\begin{array}{l}\text { Purification } \\
\text { fold }\end{array}$ & $\begin{array}{l}\text { \% } \\
\text { yield }\end{array}$ \\
\hline $\begin{array}{l}\text { Crude } \\
\mathbf{7 0 \%}\left(\mathbf{N H}_{4}\right)_{2} \mathbf{S O}_{4}\end{array}$ & 600 & 1.220 & 732 & 17 & 10,200 & 13.9 & 1 & 100 \\
$\begin{array}{l}\text { Sephadex G-100 } \\
\text { Gel filtration }\end{array}$ & 30 & 0.727 & 43.6 & 26 & 1,560 & 35.8 & 2.6 & 15.3 \\
\hline & 0.488 & 14.6 & 27 & 810 & 55.4 & 4.0 & 51.9 \\
\hline
\end{tabular}

Table 2: The various thermodynamic parameters used in characterizing the enzyme.

\begin{tabular}{llllllll}
\hline $\mathbf{T}\left({ }^{\circ} \mathbf{K}\right)$ & $\mathbf{K d}$ & $\mathbf{t}^{1} \mathbf{2}(\mathbf{m i n})$ & $\mathbf{D}-\mathbf{v a l u e}$ & $\mathbf{\Delta H}(\mathbf{K J} / \mathbf{m o l})$ & $\mathbf{E a}(\mathbf{K J} / \mathbf{m o l})$ & $\Delta \mathbf{G}(\mathbf{K J} / \mathbf{m o l})$ & $\Delta \mathbf{S}(\mathbf{K J} / \mathbf{m o l})$ \\
\hline 323 & 0.0020 & 346.57 & 1151.29 & -2642.19 & -21.616 & 96008.64 & -305.42 \\
333 & 0.0054 & 128.36 & 426.40 & -2790.17 & -21.616 & 96315.59 & -297.61 \\
343 & 0.0088 & 78.76 & 261.65 & -2873.31 & -21.616 & 97901.63 & -293.80 \\
353 & 0.0865 & 8.01 & 26.61 & -2956.45 & -21.616 & 94132.33 & -275.03 \\
363 & 0.0793 & 8.74 & 29.03 & -3039.59 & -21.616 & 97146.75 & -275.99 \\
\hline
\end{tabular}

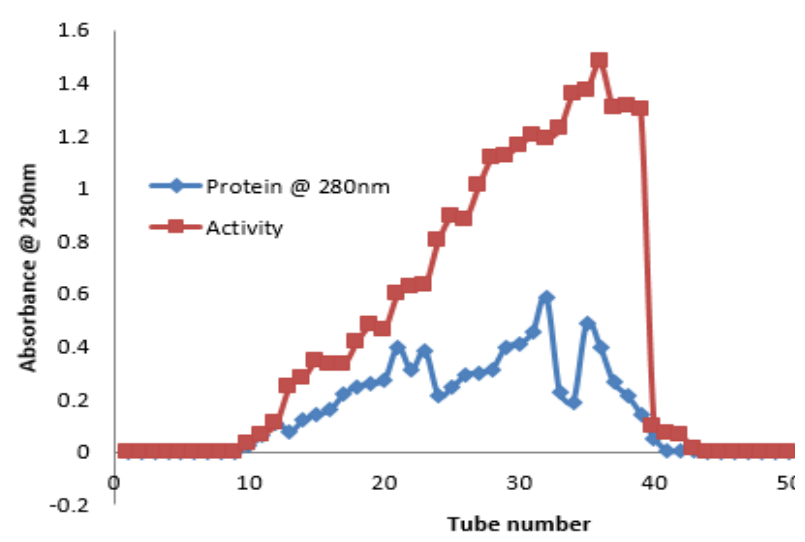

Fig 1 Elution profile of oil palm leaves peroxidase

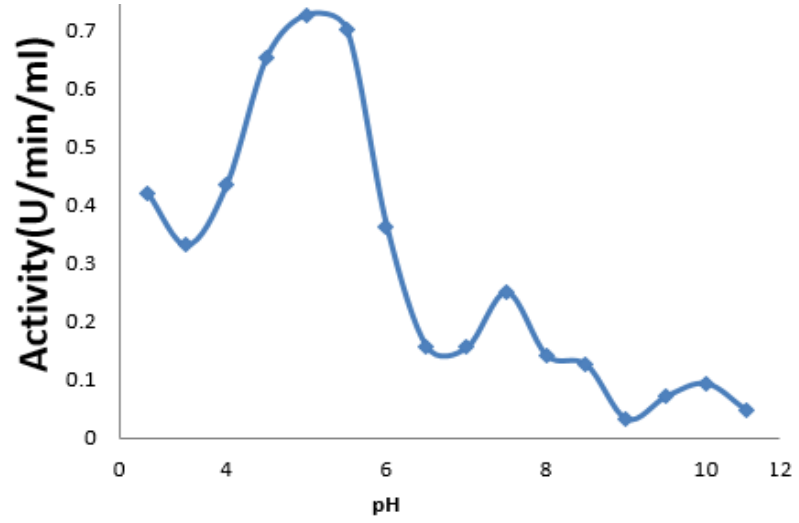

Fig 2: Optimum $\mathrm{pH}$ on activity of peroxidase from E.guineens 


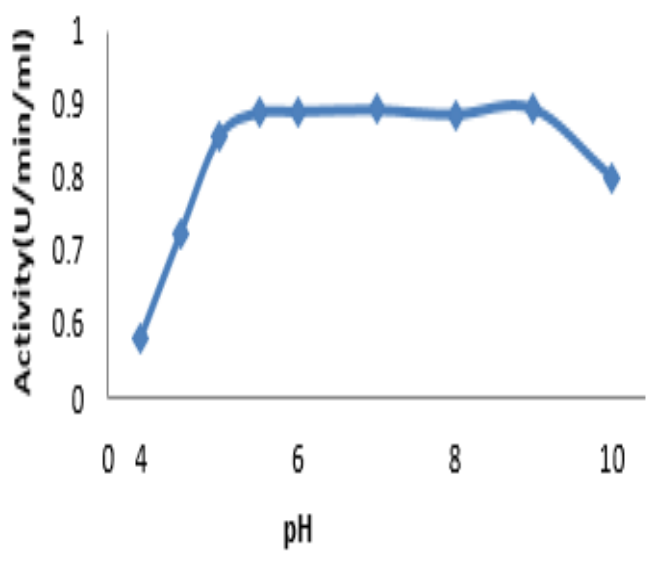

Fig 3: pH stability of peroxidase from oil palm leaf

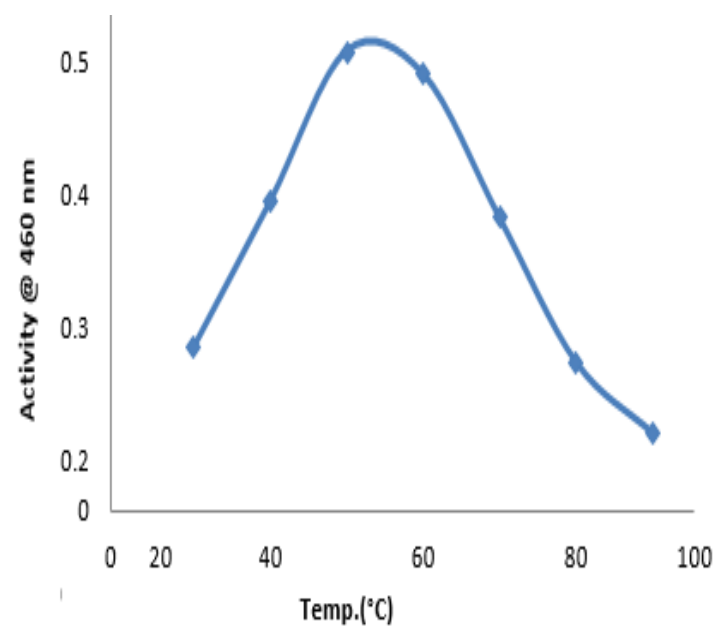

Fig 4: Optimum temperature of peroxidase from oil palm leaves

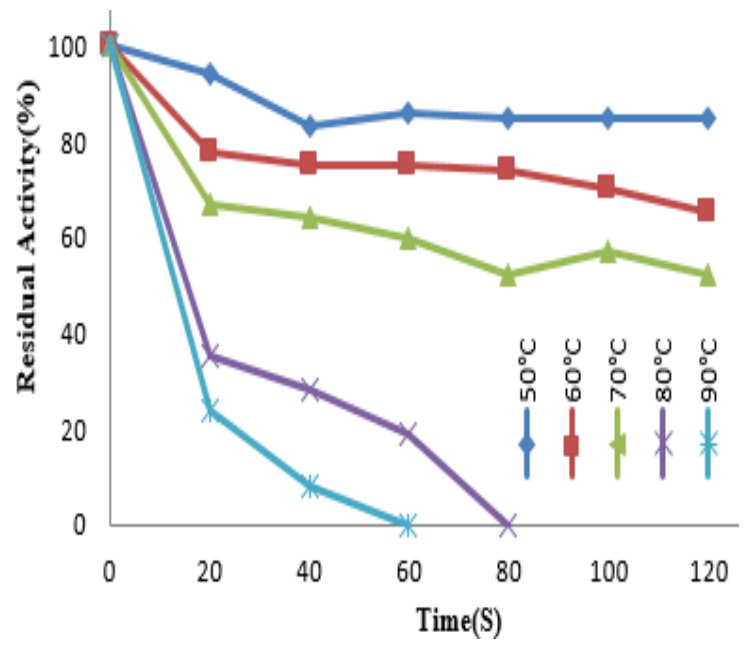

Fig 5: Temperature sensitivity of peroxidase from oil palm leaves

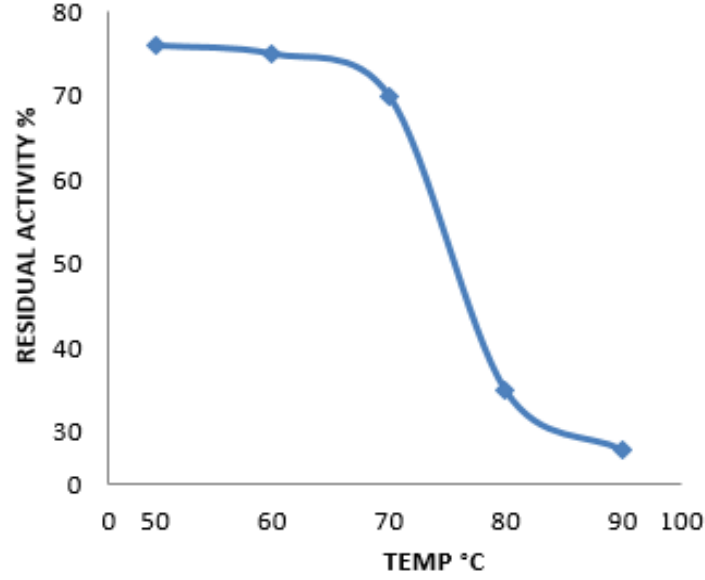

Fig 6: Temperature stability of peroxidase from oil palm leaves

Table 2 shows the various thermodynamic parameters used in characterizing the enzyme. The half-life was decreased as the temperature increased from $30-50^{\circ} \mathrm{C}$. At $60^{\circ} \mathrm{C}$ the temperature increased to $8.74 \mathrm{~min}$ showing that the time taken for loss of $50 \%$ of the enzyme activity was higher than that obtained for $50^{\circ} \mathrm{C}$. It was also observed that the D-values (the time required to reduce the peroxidase activity by $90 \%$ ) decreased with increase in time of incubation. Entropy is the measure of the degree of randomness of a system. $+\Delta S$ indicates increase in entropy while $-\Delta S$ indicates decrease in entropy. A higher rate constant (Kd) of denaturation would imply a less stable enzyme. $\Delta \mathrm{H}$ is the amount of heat required to denature the enzyme. A large and positive $\Delta \mathrm{H}$ could be associated with a more stable enzyme. Gibb's free energy $(\Delta G)$ indicates if a reaction will be energetically favourable. Negative free energy $(-\Delta G)$ indicates that the reaction is thermodynamically favourable in the direction indicated (without energy input). The change in free energy $(\Delta \mathrm{G})$ can be used to predict the direction of a reaction at constant temperature and pressure (Enachi et al., 2019).

Conclusion: Peroxidase from oil palm (Elaeis guineensis) leaves was under-studied. Result from the present study showed that peroxidase from Elaeis guineensis had its optimum $\mathrm{pH}$ of 5.0 and optimum temperature of $50^{\circ} \mathrm{C}$. It was also stable at $\mathrm{pH}$ of 5 and temperature of $50^{\circ} \mathrm{C}$.

\section{REFERENCES}

Agunbiade, O. J., Famutimi, O. G., Kadiri, F. A., Kolapo, O. A. and Adewale, I .O. (2021). Studies on peoxidase from Moringa oleifera lam leaves. Heliyon, 7: e06032.

Enachi, E., Grigore-Gurgu, L., Aprodu, L., Stanciuc, N., Dalmadi, I., Bahrim, G., Rapeanu, G. and 
Croitoru, C. (2019). Extraction, purification and processing stability of peroxidase from plums (Prunus domestica). International Journal of food properties, 21(1):2744-2757.

Eze, S.O.O., Chilaka, F.C. and Nwanguma, B.C. (2010).Purification and characterization of Sorghum (KSV8) peroxidase. Plant Production Resource Journal, 5: 51-59.

Eze, S.O.O. (2012). Kinetic analysis of the thermostability of peroxidase from African oil bean (Pentaclethra macrophylla Benth) seeds. Journal of Biochemical Technology 4(1) 459-463

Falade, A. O., Mabinya, L. V., Okoh, A. I. and Nwodo, U. U. (2019). Studies on peroxidase production and detection of Sporotrichum thermophile like catalase peroxidase gene in Bacillus species isolated from Hogsback forest reserve, South Africa. Heliyon, 5:12.

Idesa, G. O. and Getachew, B. (2018). Extraction and purification of peroxidase enzyme from plant sources for antibody labeling. International Journal of Veterinary Science and Technology, 2(1): 006-012.

Omeje, K. O., Eze, S. O. O. and Chilaka, F. C. (2017). Studies on the energetic of heat inactivation of peroxidase from green colored Solanum aethiopicum fruit. Journal of thermodynamics and catalysis, 8: 3.

Omeje, K. O. and Eze, S. O. O. (2018). Properties of partially purified peroxidase extracted from the fruit of Solanum spp grown in Enugu north (Variety A) and Plateau central (variety B) zones of Nigeria. Biokemistri, 30(1): 1-12.

Omeje, K. O., Ezema, B. O., Ozioko, J. N., Eze, S. O. O. and Chilaka, F. C. (2019). Inhibitory studies of peroxidase from infected African egg plant (Solanum aethiopicum) fruit. Journal of Applied Sciences and Environmental Management, 23(11): 1949-1955.

Qayyum, S., Nasir, A., Mian, A. H., Rehman, S., Siddiqui, M. F. and Kalsoom, U. (2020). Extraction of peroxidase enzyme from different vegetables for biodetoxification of vat dyes. Applied Nanoscience, 10: 5191-5199.

Rodriguez, A., Pina, D.G., Yelamos, B., Zhadan, G.G., Villar, E.,Roig, G.M. and Sakharov, I.Y. (2002). Thermal stability of peroxidase from the African oil palm tree (Elaeis guineensis). European Journal of Biochemistry, 10: 1432-1437.

Veda, P.P., Manika, A., Swati,S., Sameeksha, T. and Upendra, N.D. (2017). A comprehensive review on function and application of plant peroxidases. Biochemistry and Analytical Biochemistry, 6:1 